This is an electronic reprint of the original article. This reprint may differ from the original in pagination and typographic detail.

Author(s): Vasko, Petra; Wang, Shuai; Tuononen, Heikki; Power, Philip P.

Title: $\quad$ Addition of Ethylene or Hydrogen to a Main-Group Metal Cluster under Mild Conditions

Year: $\quad 2015$

Version:

Please cite the original version:

Vasko, P., Wang, S., Tuononen, H., \& Power, P. P. (2015). Addition of Ethylene or Hydrogen to a Main-Group Metal Cluster under Mild Conditions. Angewandte Chemie International Edition, 54(12), 3802-3805.

https://doi.org/10.1002/anie.201411595

All material supplied via JYX is protected by copyright and other intellectual property rights, and duplication or sale of all or part of any of the repository collections is not permitted, except that material may be duplicated by you for your research use or educational purposes in electronic or print form. You must obtain permission for any other use. Electronic or print copies may not be offered, whether for sale or otherwise to anyone who is not an authorised user. 


\title{
Addition of Ethylene or Hydrogen to a Main Group Metal Cluster under Mild Conditions
}

\author{
Petra Vasko, ${ }^{[a]}$ Shuai Wang, ${ }^{[b]}$ Heikki M. Tuononen, ${ }^{*[a]}$ and Philip P. Power ${ }^{*[b]}$
}

\begin{abstract}
Reaction the tin cluster $\mathrm{Sn}_{8}\left(\mathrm{Ar}^{\mathrm{Me}_{6}}\right)_{4}\left(\mathrm{Ar}^{\mathrm{Me}_{6}}=\mathrm{C}_{6} \mathrm{H}_{3}-2,6-\right.$ $\left.\left(\mathrm{C}_{6} \mathrm{H}_{3}-2,4,6-\mathrm{Me}_{3}\right)_{2}\right)$ with excess ethylene or dihydrogen at $25{ }^{\circ} \mathrm{C} / 1$ atmosphere yielded two new clusters that incorporated ethylene or hydrogen. The reaction with ethylene yielded $\mathrm{Sn}_{4}\left(\mathrm{Ar}^{\mathrm{Me}}\right)_{4}\left(\mathrm{C}_{2} \mathrm{H}_{2}\right)_{5}$ that contained five ethylene moieties bridging four aryl substituted tin atoms and one tin-tin bond. Reaction with $\mathrm{H}_{2}$ produced a cyclic tin species of formula $\left(\mathrm{Sn}(\mathrm{H}) \mathrm{Ar}^{\mathrm{Me}} 6\right)_{4}$ which could also be synthesized by the reaction of $\left\{\left(\mathrm{Ar}^{\mathrm{Me}}\right) \mathrm{Sn}(\mu-\mathrm{Cl})\right\}_{2}$ with DIBAL-H. These reactions represent the first instances of direct reactions of isolable main group clusters with ethylene or hydrogen under mild conditions. The products were characterized in the solid state by X-ray diffraction and IR spectroscopy and by multinuclear NMR and UV-Vis spectroscopy. Density functional theory calculations were performed to explain the reactivity of the cluster.
\end{abstract}

In 2005 it was shown that a main group molecule could react with dihydrogen at room temperature and atmospheric pressure. ${ }^{[1]}$ Since then a wide variety of main group compounds have been investigated for their reactions with small molecules under mild conditions. ${ }^{[2-5]}$ Such reactions are dependent on the existence of donor and acceptor orbitals of suitable symmetry and modest energy separation. ${ }^{[6]}$ Thus, multiply bonded or unsaturated main group species have commonly been used. For example, heavier group 14 alkyne, $\mathrm{Ar}^{\mathrm{iPr}} \mathrm{PEEAr}^{\mathrm{iPr}}{ }_{4}$, and carbene, : $\mathrm{E}\left(\mathrm{Ar}^{\mathrm{iPr}}\right)_{2}$, analogues $\left(\mathrm{E}=\mathrm{Ge}\right.$ or $\mathrm{Sn} ; \mathrm{Ar}^{\mathrm{iPr}}{ }_{4}=\mathrm{C}_{6} \mathrm{H}_{3}-2,6$ $\left.\left(\mathrm{C}_{6} \mathrm{H}_{3}-2,6-\mathrm{PPr}_{2}\right)_{2}\right)$ react readily with hydrogen, ethylene and other small molecules under mild conditions. ${ }^{[7-10]}$ Activation of small molecules can also be effected by stable carbenes such as : $\mathrm{C}(\mathrm{tBu})(\mathrm{iPr})_{2} \mathrm{~N}^{[5,11]}$ or frustrated Lewis pairs using a phosphine or related electron donor and $\mathrm{B}\left(\mathrm{C}_{6} \mathrm{~F}_{5}\right)_{3}$ as the acceptor. ${ }^{[12]}$ Several reactions have been shown to be reversible, which also has generated widespread interest. ${ }^{[13-15]}$ The reactivity of these main group compounds toward small molecules can resemble that of transition metal complexes, and thus, may have use in catalytic applications. ${ }^{[16]}$

The reactivity of main group clusters towards small molecules under ambient conditions has remained virtually unexplored. ${ }^{[17]}$ There have been a few theoretical studies on

\footnotetext{
[a] P. Vasko and Senior Lecturer H. M. Tuononen University of Jyväskylä Department of Chemistry Nanoscience Center P.O. Box 35, Fl-40014 University of Jyväskylä E-mail: heikki.m.tuononen@jyu.fi

[b] S. Wang and Professor P. P. Power Department of Chemistry

University of California, Davis

One Shields Avenue, Davis, CA, 95616

E-mail: pppower@ucdavis.edu
}

dihydrogen activation by aluminum clusters ${ }^{[18]}$ and the activation of ammonia-borane by a gallium nitrogen cage compound. ${ }^{[19]}$ Main group molecular clusters are also of interest because the coordination of their constrained atoms may resemble that of atoms at elemental surfaces. ${ }^{[20-23]}$ Herein we report the reactions of the tin cluster $\mathrm{Sn}_{8}\left(\mathrm{Ar}^{\mathrm{Me}}\right)_{4}\left(\mathrm{Ar}^{\mathrm{Me}} 6=\mathrm{C}_{6} \mathrm{H}_{3}-2,6-\left(\mathrm{C}_{6} \mathrm{H}_{2}-2,4,6-\right.\right.$ $\left.\left(\mathrm{Me}_{3}\right)_{2}\right)^{[20]}$ with excess ethylene or dihydrogen to afford the products 1 and 2 as depicted in Scheme 1. The product 1 shows that the initial cluster has absorbed five ethylene molecules. A reaction between the tin cluster and dihydrogen yields the tin hydride 2. Significantly, both reactions involve the loss of the unsubstituted tin atoms in the cluster. The syntheses of $\mathbf{1}$ and $\mathbf{2}$ are described as well as their characterization by NMR spectroscopy and X-ray crystallography. Computational investigations of model systems for $\mathbf{1}$ and $\mathbf{2}$ are also described.

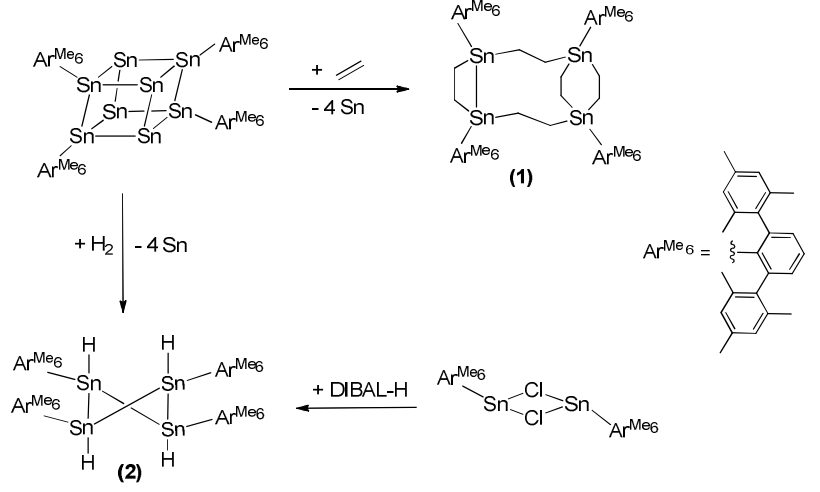

Scheme 1. Reactions of $\mathrm{Sn}_{8}\left(\mathrm{Ar}^{\mathrm{Me}}\right)_{6}$ with excess ethylene or $\mathrm{H}_{2}$, and a reaction of $\left\{\left(\mathrm{Ar}^{\mathrm{Me}_{6}}\right) \mathrm{Sn}(\mu-\mathrm{Cl})\right\}_{2}$ with DIBAL-H in 1:4 molar ratio.

Compound 1 was synthesized by treating $\mathrm{Sn}_{8}\left(\mathrm{Ar}^{\mathrm{Me}} 6\right)_{4}{ }^{[20]}$ in THF with ethylene under ambient conditions (Scheme 1). The initially dark purple mixture was stirred for 2.5 days at $25{ }^{\circ} \mathrm{C}$ to afford a dark red solution and a metallic precipitate, assumed to be elemental tin. After work-up, compound 1 was isolated in $14 \%$ yield. Colorless crystals were grown from diethyl ether at $6{ }^{\circ} \mathrm{C}$ overnight. Compound 1 crystallizes in a triclinic $\mathrm{P} 1$ space group with two diethyl ether solvent molecules. ${ }^{[24]}$ Figure 1 depicts the solid state structure of $\mathbf{1}$ and it can be seen that the initial tin cluster, $\mathrm{Sn}_{8}\left(\mathrm{Ar}^{\mathrm{Me}}\right)_{4}$, has incorporated five ethylene molecules and the four unsubstituted tin atoms have been eliminated. One $\mathrm{C}_{2} \mathrm{M}_{4}$ moiety is disordered over two positions, each with $50 \%$ occupancy and only one of these sites (C7A and C8A) is shown. 


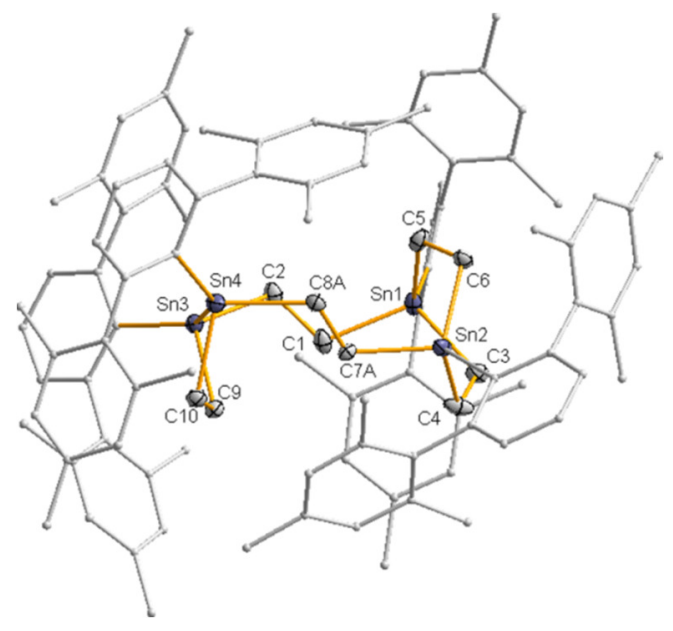

Figure 1. X-ray crystal structure of $1 \cdot 2 \mathrm{Et}_{2} \mathrm{O}$. One of the disordered ethylene (C7B-C8B) positions, solvent molecules and hydrogen atoms are not shown for clarity. Thermal ellipsoids are drawn with $30 \%$ probability. Selected bond lengths $(\AA)$ and angles $\left({ }^{\circ}\right.$ : : Sn(3)-Sn(4): 2.8549(5) Sn(1)-C(1): 2.181(4) C(1)$C(2): 1.538(6) \mathrm{Sn}(3)-C(9): 2.208(4) \mathrm{Sn}(3)-C(59): 2.205(4), C(1)-S n(1)-C(3):$ 108.82(17), C(1)-Sn(1)-C(5): 106.15(17), C(2)-Sn(3)-C(9): 110.36(16).

Each tin is tetrahedrally coordinated and carries one $\mathrm{Ar}^{\mathrm{Me}} 6$ ligand. Two tins, $S n(1)$ and $S n(2)$, are bound also to three carbon atoms from different ethylenes whereas $\mathrm{Sn}(3)$ and $\mathrm{Sn}(4)$ are bonded to two carbon atoms from bridging ethylenes as well as to each other. Thus there is one intact $\mathrm{Sn}-\mathrm{Sn}$ bond (i.e. $\mathrm{Sn}(3)-\mathrm{Sn}(4), \mathbf{1}$, $2.8549(5) \AA)$, similar in length to the ethylene bridged tin-tin single bond in $\operatorname{Ar}^{\mathrm{iPr}}{ }_{4} \mathrm{Sn}\left(\mu_{2}: \eta^{1}: \eta^{1}-\mathrm{C}_{2} \mathrm{H}_{4}\right)_{2} \mathrm{SnAr}^{\mathrm{iPr}}{ }_{4}$, formed by reversible addition of ethylene to the distannyne

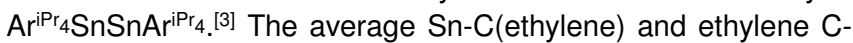
$\mathrm{C}$ bond lengths are $2.177 \AA$ and $1.527 \AA$, respectively. These are normal for Sn-C and C-C single bonds. ${ }^{[2,26]}$ Interligand angles at the tin atoms are near $109.5^{\circ}$ indicating tetrahedral geometry although disorder at the C7-C8 moiety and Sn-Sn bond cause deviation from the ideal value. The ${ }^{1} \mathrm{H}$ and ${ }^{13} \mathrm{C}$ NMR spectra of compound $\mathbf{1}$ indicate the presence of symmetry in the molecule in solution as only two unique sets of signals corresponding to $\mathrm{Ar}^{\mathrm{Me}} 6$ ligand environments are observed. The ${ }^{119} \mathrm{Sn}$ NMR spectrum reveals two signals at 336.0 [Sn(3) and $\mathrm{Sn}(4)]$ and $1.1 \mathrm{ppm}[\mathrm{Sn}(1)$ and $\mathrm{Sn}(2)]$, indicating two tin environments whose chemical shifts are consistent with reported values. ${ }^{[8]}$

The reaction of $\mathrm{Sn}_{8}\left(\mathrm{Ar}^{\mathrm{Me}} 6\right)_{4}$ with excess of $\mathrm{H}_{2}$ was conducted similarly and yielded the tetrameric tin(II) hydride 2 (Figure 2 ) in low yield. It was characterized by single crystal X-ray diffraction. ${ }^{[24]}$ The low yield is due probably to the reaction conditions which required mild heating in THF, and which decompose the majority of the starting cluster with deposition of elemental tin. Hence, the tin hydride 2 was synthesized in a more straightforward manner by the reaction of the precursor $\left\{\left(\mathrm{Ar}^{\mathrm{Me}_{6}}\right) \mathrm{Sn}(\mu-\mathrm{Cl})\right\}_{2}{ }^{[27]}$ with diisobutylaluminum hydride (DIBAL-H) (Scheme 1). A solution of DIBAL-H in hexanes was added dropwise to a diethyl ether solution of $\left\{\left(\operatorname{Ar}^{\mathrm{Me}_{6}}\right) \operatorname{Sn}(\mu-\mathrm{Cl})\right\}_{2}$. The initially yellow solution turned orange and after workup compound 2 was collected as yellow crystals in $21 \%$ yield.
Compound 2 crystallizes in an orthorhombic Fddd space group. The asymmetric unit consists of a $\mathrm{Sn}(\mathrm{H})\left(\mathrm{Ar}^{\mathrm{Me}} 6\right)$ moiety and $0.5 \mathrm{Et}_{2} \mathrm{O}$, with the rest of the molecule generated by symmetry. It consists of a puckered ring of four tin atoms each $\sigma$ bonded to a hydrogen and an $\mathrm{Ar}^{\mathrm{Me}_{6}}$ ligand in addition to the neighboring tins. The tin atoms are tetrahedrally coordinated. The overall tetrameric structure may be contrasted with that of the more sterically encumbered hydrogen bridged dimer $\left\{\mathrm{Ar}^{\mathrm{iPr}} 4 \mathrm{Sn}(\mu-\mathrm{H})\right\}_{2}{ }^{[28]}$ or that of the asymmetric stannylstannylene $\mathrm{Ar}^{\mathrm{iPr}} 8 \mathrm{SnSn}(\mathrm{H})_{2} \mathrm{Ar}^{\mathrm{iPr}{ }_{8}[29]}$ and related species. ${ }^{[30]}$ The orientation of the hydrogens alternate on either side of the $\mathrm{Sn}_{4}$. The $\mathrm{Sn}-\mathrm{Sn}$ bond lengths (2.8433(4) and 2.8050(3) $\AA$ ) are slightly shorter than the Sn-Sn single bonds in the other terminal tin hydrides, ${ }^{[29,30]}$ but within the range of typical $\mathrm{Sn}-\mathrm{Sn}$ single bonds. There are a few structures in the literature that incorporate a $\mathrm{Sn}_{4}$ ring, but none have $\mathrm{Sn}-\mathrm{H}$ bonds. The known species have formulas $\mathrm{Sn}_{4} \mathrm{~L}_{8}\left(\mathrm{~L}=\right.$ alkyl ligand) or $\mathrm{Sn}_{4} \mathrm{~L}_{4}^{\prime}\left(\mathrm{L}^{\prime}=\right.$ bidentate ligand) ${ }^{[31-33]}$ The ${ }^{1} \mathrm{H}$ NMR spectrum of 2 shows a hydride signal at $3.97 \mathrm{ppm}$, and the ${ }^{119} \mathrm{Sn} \mathrm{NMR}$ spectrum at $-24.3 \mathrm{ppm}, \mathrm{J}_{\mathrm{Sn}-\mathrm{H}}=$ $1590 \mathrm{~Hz} \cdot{ }^{[34]}$

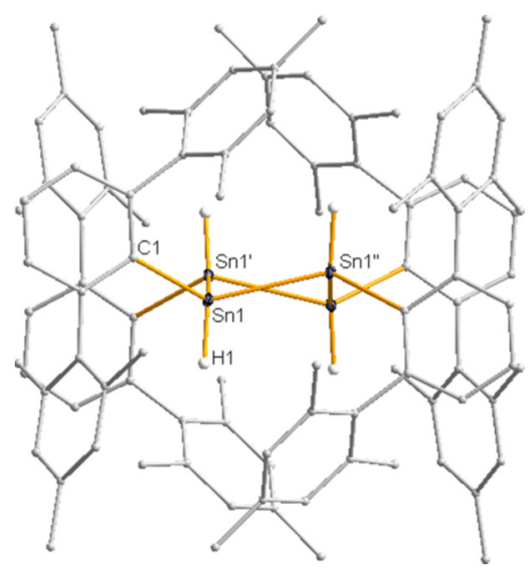

Figure 2. X-ray crystal structure of $\mathbf{2} \cdot 2 \mathrm{Et}_{2} \mathrm{O}$. Solvent molecule and aryl hydrogen atoms are not shown for clarity. Thermal ellipsoids are drawn with $30 \%$ probability. Selected bond lengths $(\AA \AA)$ and angles $\left({ }^{\circ}\right)$ : $\operatorname{Sn}(1)-\operatorname{Sn}\left(1^{\prime}\right)$ : 2.8433(4), Sn(1)-Sn(1"): 2.8050(3), Sn(1)-C(1): 2.173(3), Sn(1)-H(1): 1.47(5), C(1)-Sn(1)-Sn(1'): 130.89(7), Sn(1)-Sn(1')-Sn(1'): 87.030(3).

The reactivity of the tin cluster towards $\mathrm{H}_{2}$ and ethylene was investigated computationally using the PBEO hybrid functional[35${ }^{38]}$ with def2-TZVP basis sets. ${ }^{[38]} \mathrm{A}$ model compound $\mathrm{Sn}_{8} \mathrm{Ph}_{4}$ was used to lower computational cost. The calculations show that the reaction of dihydrogen with the $\mathrm{Sn}_{8} \mathrm{Ph}_{4}$ cluster yields an addition product $\mathrm{Sn}_{8}\left(\mathrm{H}_{2}\right) \mathrm{Ph}_{4}$ (Figure 3) initially, whose formation is thermodynamically disfavored in the gas phase $\left(\Delta \mathrm{H}=4 \mathrm{~kJ} \mathrm{~mol}^{-1}\right.$; $\left.\Delta \mathrm{G}=39 \mathrm{~kJ} \mathrm{~mol}^{-1}\right)$. The Gibbs energy or activation was found to be $134 \mathrm{~kJ} \mathrm{~mol}^{-1}$, consistent with the fact that the reaction with $\mathrm{H}_{2}$ required mild heating and an excess of hydrogen gas to proceed. A similar addition product was located for the reaction of $\mathrm{Sn}_{8} \mathrm{Ph}_{4}$ with ethylene (see Figure 3 ). However, the gas phase reaction is exothermic and only slightly disfavored by entropy $(\Delta \mathrm{H}=-33 \mathrm{~kJ}$ $\left.\mathrm{mol}^{-1} ; \Delta \mathrm{G}=22 \mathrm{~kJ} \mathrm{~mol}^{-1}\right)$. The Gibbs energy of activation is also significantly smaller, $86 \mathrm{~kJ} \mathrm{~mol}^{-1}$, consistent with experimental observations. 
The frontier orbitals of $\mathrm{Sn}_{8} \mathrm{Ph}_{4}$ have both electron donating and accepting features (see $\mathrm{SI}$ ), which rationalizes the relatively facile formation of $\mathrm{Sn}_{8}\left(\mathrm{H}_{2}\right) \mathrm{Ph}_{4}$ and $\mathrm{Sn}_{8}\left(\mathrm{C}_{2} \mathrm{H}_{4}\right) \mathrm{Ph}_{4}$. The modelling of mechanisms for the formation of $\{\mathrm{Sn}(\mathrm{H}) \mathrm{Ph}\}_{4}, \mathrm{Sn}_{4} \mathrm{Ph}_{4}\left(\mathrm{C}_{2} \mathrm{H}_{4}\right)_{5}$, and elemental tin is beyond the scope of this work. However, the peculiar structure of $\mathbf{1}$ with an unreacted $\mathrm{Sn}-\mathrm{Sn}$ bond prompted us to investigate the possible insertion of a sixth ethylene to $\mathrm{Sn}_{4} \mathrm{Ph}_{4}\left(\mathrm{C}_{2} \mathrm{H}_{4}\right)_{5}$ to form $\mathrm{Sn}_{4} \mathrm{Ph}_{4}\left(\mathrm{C}_{2} \mathrm{H}_{4}\right)_{6}$. The structures of ethylene, $\mathrm{Sn}_{4} \mathrm{Ph}_{4}\left(\mathrm{C}_{2} \mathrm{H}_{4}\right)_{5}$ and $\mathrm{Sn}_{4} \mathrm{Ph}_{4}\left(\mathrm{C}_{2} \mathrm{H}_{4}\right)_{6}$ were optimized (see $\mathrm{SI}$ ) and their energies compared, which revealed that the addition of a sixth equivalent of ethylene is thermodynamically favored $(\Delta \mathrm{G}=$ $-12 \mathrm{~kJ} \mathrm{~mol}^{-1}$ ) though the reaction could be prevented by kinetic factors. Unfortunately, we could not locate a transition state for the addition of the sixth ethylene molecule, thus the magnitude of the activation barrier remains unknown.

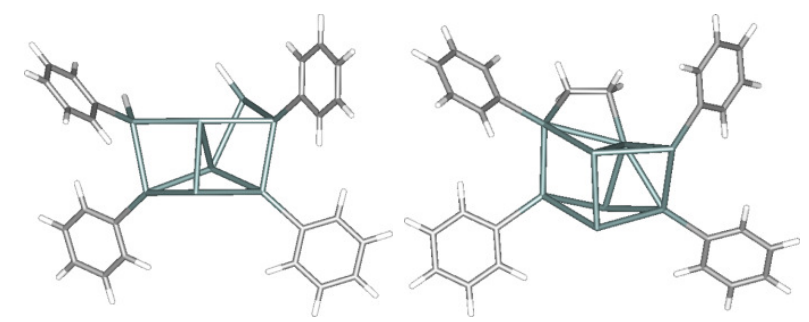

Figure 3. Optimized structures for the addition products of $\mathrm{Sn}_{8} \mathrm{Ph}_{4}$ with $\mathrm{H}_{2}$ (left) and ethylene (right).

In summary, we have described the syntheses and characterization data for two new insertion products of small molecules to a tin cluster under mild conditions. Further studies on the reactivity of $\mathrm{Sn}_{8}\left(\mathrm{Ar}^{\mathrm{Me}}\right)_{4}$ towards other small molecules and attempts to prepare $\left.\mathrm{Sn}_{4}\left(\mathrm{Ar}^{\mathrm{Me}}\right)_{4}\right)_{4}\left(\mathrm{C}_{2} \mathrm{H}_{4}\right)_{6}$ are on-going.

\section{Experimental Section}

All manipulations were carried out under anaerobic and anhydrous conditions by using modified Schlenk line techniques under a dinitrogen atmosphere or in a Vacuum Atmospheres HE-43 drybox. Solvents were dried and stored over sodium. Physical measurements were performed under anaerobic and anhydrous conditions. ${ }^{1} \mathrm{H},{ }^{13} \mathrm{C}\left\{{ }^{1} \mathrm{H}\right\}$ and ${ }^{119} \mathrm{Sn}\left\{{ }^{1} \mathrm{H}\right\}$ NMR spectra were obtained on a Varian 400 or $600 \mathrm{MHz}$ spectrometers and referenced to known standards. IR spectra were recorded as Nujol mulls between CsI plates on a Perkin-Elmer 1430 Infrared Spectrometer. UV-visible spectra were recorded as dilute toluene solutions in $3.5 \mathrm{~mL}$ quartz cuvette using an Olis 17 Modernized Cary 14 UV/Vis/NIR Spectrophotometer. Melting points were determined on a Meltemp II apparatus using glass capillaries sealed with vacuum grease, and are uncorrected. All starting materials were obtained from commercial sources and used as received. $\mathrm{Sn}_{8}\left(\mathrm{Ar}^{\mathrm{Me}_{6}}\right)_{4}{ }^{[20]}$ and $\left\{\left(\mathrm{Ar}^{\mathrm{Me}} 6\right) \mathrm{Sn}(\mu-\mathrm{Cl})\right\}_{2},{ }^{[27]}$ were prepared by literature procedures.

Synthesis of $\mathrm{Sn}_{4}\left(\mathrm{Ar}^{\mathrm{Me}_{6}}\right)_{4}\left(\mathrm{CH}_{2} \mathrm{CH}_{2}\right)_{5}$ (1). $0.700 \mathrm{~g}$ of $\mathrm{Sn}_{8}\left(\mathrm{Ar}^{\mathrm{Me}}\right)_{4}$ was dissolved in ca. $40 \mathrm{~mL}$ of THF. The flask was flushed with ethylene gas for ca. $45 \mathrm{~min}$ at $25^{\circ} \mathrm{C}$ and then stirred under an ethylene atmosphere for another $48 \mathrm{~h}$. The initially dark purple solution became dark red with a grey precipitate (assumed to be elemental tin). The mixture was allowed to settle and filtered. The filtrate was evaporated and the residue was dissolved in ca. $20 \mathrm{~mL}$ of $\mathrm{Et}_{2} \mathrm{O}$. Filtration followed by reduction in volume to ca. $6 \mathrm{~mL}$ and storage at $6{ }^{\circ} \mathrm{C}$ overnight yielded colorless crystals of 1 which were dried under vacuum. Yield $0.080 \mathrm{~g}(14 \%) .{ }^{1} \mathrm{H}$ NMR $\left(25{ }^{\circ} \mathrm{C}\right.$, $\left.\mathrm{C}_{6} \mathrm{D}_{6}, 600 \mathrm{MHz}\right): \delta=-0.10\left(\mathrm{t},{ }^{3} \mathrm{~J}_{\mathrm{HH}}=8.0 \mathrm{~Hz}, 4 \mathrm{H}, \mathrm{Sn}-\mathrm{CH}_{2} \mathrm{CH}_{2}-\mathrm{Sn}\right), 0.11(\mathrm{~m}$, $\left.{ }^{3} \mathrm{~J}_{\mathrm{HH}}=8.0 \mathrm{~Hz}, 4 \mathrm{H}, \mathrm{Sn}-\mathrm{CH}_{2} \mathrm{CH}_{2}-\mathrm{Sn}\right), 0.52\left(\mathrm{t},{ }^{3} \mathrm{~J}_{\mathrm{HH}}=24.0 \mathrm{~Hz}, 8 \mathrm{H}, \mathrm{Sn}-\right.$ $\mathrm{CH}_{2} \mathrm{CH}_{2}-\mathrm{Sn}$ ), 0.74 (t, $\left.{ }^{3} \mathrm{JHH}_{\mathrm{HH}}=8.0 \mathrm{~Hz}, 4 \mathrm{H}, \mathrm{Sn}-\mathrm{CH}_{2} \mathrm{CH}_{2}-\mathrm{Sn}\right), 2.04$ (s, 24H, Mes- $\mathrm{CH}_{3}$ ), 2.07 (s, 24H, Mes- $\left.\mathrm{CH}_{3}\right), 2.29$ (s, 12H, Mes- $\left.\mathrm{CH}_{3}\right), 2.34$ (s, 12H, Mes- $\mathrm{CH}_{3}$ ) 6.83, 6.84, 6.87, 6.91, 7.19 ppm (aromatic $\left.\mathrm{H}, 28 \mathrm{H}\right),{ }^{13} \mathrm{C}\left\{{ }^{1} \mathrm{H}\right\}$ NMR $\left(25{ }^{\circ} \mathrm{C}, \mathrm{C}_{6} \mathrm{D}_{6}, 151 \mathrm{MHz}\right): \delta=6.5,9.2,9.5,13.9,14.4,19.8$ $\left(\mathrm{CH}_{2} \mathrm{CH}_{2}\right), 21.4$, 21.6, 21.6, 23.1 (Mes- $\left.\mathrm{CH}_{3}\right), 31.9\left(\mathrm{CH}_{2} \mathrm{CH}_{2}\right), 128.4,128.4$, $128.6,129.0,129.2,129.3,136.2,136.5,141.9,142.7,147.2$ and 150.2 ppm (aromatic C), three ipso-C signals were not observed, ${ }^{119} \mathrm{Sn}\left\{{ }^{1} \mathrm{H}\right\}$ NMR $\left(25^{\circ} \mathrm{C}, \mathrm{C}_{6} \mathrm{D}_{6}, 149 \mathrm{MHz}\right): 336.0(\mathrm{Sn}-\mathrm{Sn})$ and 1.1ppm $\left(\mathrm{Sn}-\mathrm{CH}_{2} \mathrm{CH}_{2}\right)$. Melting point: $152-155{ }^{\circ} \mathrm{C}$ (decomp.). IR in Nujol mull $\left(\mathrm{cm}^{-1}\right)$ with Csl plates: $650,520,475,335$ and 315 (Sn-C, stretching and bending). UVVis (toluene, $\mathrm{nm}$ ): 307,321 and 330.

Synthesis of $\left\{\mathrm{Sn}(\mathrm{H})\left(\mathrm{Ar}^{\mathrm{Me}}{ }_{6}\right)\right\}_{4}$ (2). Method A. $\mathrm{Sn}_{8}\left(\mathrm{ArMe}_{6}\right)_{4}(0.661 \mathrm{~g})$ was dissolved in ca. $25 \mathrm{~mL}$ of toluene and warmed to $60{ }^{\circ} \mathrm{C}$. The mixture was stirred under an $\mathrm{H}_{2}$ atmosphere for $3.5 \mathrm{~h}$ and then cooled to room temperature. Stirring was continued overnight without any color change but a significant amount of grey precipitate (elemental tin) was formed. The precipitate was allowed to settle and the solution was filtered. The volume was reduced to ca. $10 \mathrm{~mL}$ and $5 \mathrm{~mL}$ of THF was added. The mixture was placed in a fridge. Crystals of compound 2 were collected from the mixture which contained mainly unreacted $\mathrm{Sn}_{8}\left(\mathrm{Ar}^{\mathrm{Me}}\right)_{4}$. Method B. A solution of diisobutyl aluminum hydride in hexanes $(3.2 \mathrm{~mL}, 1 \mathrm{M}, 3.2$ $\mathrm{mmol}$, diluted with $2 \mathrm{~mL}$ of hexanes) was added dropwise to the diethyl ether solution of $\left\{\left(\mathrm{Ar}^{\mathrm{Me}}\right) \mathrm{Sn}(\mu-\mathrm{Cl})\right\}_{2}{ }^{[27]} \quad(0.708 \mathrm{~g}$ in ca. $30 \mathrm{~mL}$ of diethyl ether) at $-78{ }^{\circ} \mathrm{C}$. The solution became orange and was stirred for ca. $2 \mathrm{~h}$. A green precipitate was formed and removed by filtration. Storage of the diethyl ether solution at $-30{ }^{\circ} \mathrm{C}$ overnight yielded yellow crystals of 2 . Yield $0.135 \mathrm{~g}(21 \%) .{ }^{1} \mathrm{H}$ NMR $\left(25^{\circ} \mathrm{C}, \mathrm{C}_{6} \mathrm{D}_{6}, 600 \mathrm{MHz}\right): \delta=1.66(\mathrm{~s}, 12 \mathrm{H}$, Mes- $\mathrm{CH}_{3}$ ), 1.80 (s, 12H, Mes- $\left.\mathrm{CH}_{3}\right), 2.07$ (s, 12H, Mes- $\left.\mathrm{CH}_{3}\right), 2.15(\mathrm{~s}, 12 \mathrm{H}$, Mes- $\mathrm{CH}_{3}$ ), 2.33(s, 24H, Mes- $\left.\mathrm{CH}_{3}\right), 3.97$ (s, 4H, Sn-H), 6.73, 6.77, 6.82, 7.07, 7.10, $7.12 \mathrm{ppm}$ (aromatic $\mathrm{H}, 28 \mathrm{H}) .{ }^{13} \mathrm{C}\left\{{ }^{1} \mathrm{H}\right\} \mathrm{NMR}\left(25^{\circ} \mathrm{C}, \mathrm{CDCl}_{3}, 151\right.$ $\mathrm{MHz}): \delta=21.5,21.8,22.0,22.4$ and 23.7 ppm (Mes- $\left.\mathrm{CH}_{3}\right), 128.4,128.5$, 128.7, 128.8, 128.9, 129.0, 129.3, 135.1, 135.3, 135.5, 135.7, 135.9, 136.0, 141.7, 142.0, 144.5, 150.0 and $150.2 \mathrm{ppm}$ (aromatic C), ${ }^{119} \mathrm{Sn}$ $\operatorname{NMR}\left(25^{\circ} \mathrm{C}, \mathrm{CDCl}_{3}, 149 \mathrm{MHz}\right): \delta=-324.3\left(\mathrm{~d},{ }^{1} \mathrm{~J}_{\mathrm{Sn}-\mathrm{H}}=1590 \mathrm{~Hz}, \mathrm{Sn}-\mathrm{H}\right) .{ }^{[32]}$ Melting point: $>300{ }^{\circ} \mathrm{C}$. IR in Nujol mull $\left(\mathrm{cm}^{-1}\right)$ with Csl plates: $1845(\mathrm{Sn}-\mathrm{H}$ stretching), 730 ( $\mathrm{Sn-H}$ bending). UV-Vis (toluene, $\mathrm{nm}$ ): 296 and 308.

\section{Acknowledgements}

We thank the US Department of Energy (DE-FG02-07ER4675) and the Academy of Finland for financial support. P.V. thanks the Fulbright Foundation for funding, and Michelle A. Faust and Mikko M. Hänninen for helpful discussions.

[1] G. H. Spikes, J. C. Fettinger, and P. P. Power, J. Am. Chem. Soc., 2005, 127, 12232-12233.

[2] G. C. Welch, R. R. San Juan, J. D. Masuda and D. W. Stephan, Science, 2006, 314, 1124-1126.

[3] Y. Peng, B. D. Ellis, X. Wang, and P. P. Power, J. Am. Chem. Soc., 2008, 130, 12268-12269.

[4] P. P. Power, Chem. Rec., 2012, 12, 238-255.

[5] G. D. Frey, V. Lavallo, B. Donnadieu, W. W. Schoeller, and G. Bertrand, Science, 2007, 316, 439-441.

[6] P. P. Power, Nature, 2010, 463, 171-177.

[7] O. T. Summerscales, J. C. Fettinger, and P. P. Power, J. Am. Chem. Soc., 2011, 133, 11960-11963.

[8] Y. Peng, B. D. Ellis, X. Wang, J. C. Fettinger and P. P. Power, Science, 2009, 325, 1668-1670. 
[9] S. K. Mandal and H. W. Roesky, Acc. Chem. Res., 2011, 45, 298-307.

[10] Z. D. Brown, P. Vasko, J. C. Fettinger, H. M. Tuononen, and P. P. Power, J. Am. Chem. Soc., 2012, 134, 4045-4048.

[11] V. Lavallo, Y. Canac, B. Donnadieu, W. W. Schoeller, and G. Bertrand, Angew. Chem. Int. Ed., 2006, 45, 3488-3491.

[12] D. W. Stephan, Chem. Commun., 2010, 45, 8526-8533.

[13] D. W. Stephan and G. Erker, Angew. Chem. Int. Ed., 2010, 49, 46-76.

[14] L. E. Longobardi, C. A. Russell, M. Green, N. S. Townsend, K. Wang, A. J. Holmes, S. B. Duckett, J. E. McGrady, and D. W. Stephan, J. Am Chem. Soc., 2014, 136, 13453-13457.

[15] C. M. Mömming, E. Otten, G. Kehr, R. Fröhlich, S. Grimme, D. W. Stephan, and G. Erker, Angew. Chem. Int. Ed., 2009, 48, 6643-6646.

[16] T. J. Hadlington, M. Hermann, G. Frenking, and C. Jones, J. Am. Chem. Soc., 2014, 136, 3028-3031.

[17] Molecular Clusters of the Main Group Elements, (Eds.: M. Driess and H. Nöth), Wiley-VCH, 2004

[18] J. Moc, Theor. Chem. Acc., 2013, 132, 1-15

[19] J-Y. Zhao, F-Q. Zhao, H-X. Gao, and X-H. Ju, J. Mol. Model, 2013, 19, 1789-1799.

[20] B. E. Eichler and P. P. Power, Angew. Chem. Int. Ed., 2001, 40, 796797.

[21] J. M. Buriak, Chem. Rev., 2002, 102, 1271-1308.

[22] A. F. Richards, B. E. Eichler, M. Brynda, M. M. Olmstead, and P. P. Power, Angew. Chem. Int. Ed., 2005, 44, 2546-2549.

[23] K. T. Wong, B. Shong, W. Sun, and S. F. Bent, J. Phys. Chem. C., 2013, 117, 26628-26635.

[24] Crystal data for $1 \cdot 2 \mathrm{Et}_{2} \mathrm{O}$ obtained with $\mathrm{MoK}_{\alpha}(\lambda=0.71073 \AA)$ radiation at $90 \mathrm{~K}$ : triclinic, $\mathrm{P} 1$, colorless block, $a=13.677(2), b=14.469(2), c=$ 28.358(4) $\AA, \alpha=88.555(2), \beta=78.4629(19), \gamma=72.1903(19){ }^{\circ}, Z=2$, formula $\mathrm{C}_{114} \mathrm{H}_{140} \mathrm{O}_{2} \mathrm{Sn}_{4}, \quad M=2017.01, \quad \mathrm{R}_{1}=0.0458$ for 20507 independent reflections. Crystal data for $2 \cdot 2 \mathrm{Et}_{2} \mathrm{O}$ obtained with $\mathrm{MoK}_{\alpha}(\lambda$ $=1.54178 \AA$ ) radiation at $90 \mathrm{~K}$ : orthorhombic $F_{\text {ddd }}$, colorless block, $a=$ 14.5564(3), $b=30.5444(7), \quad c=39.8150(10) \AA, Z=8$, formula $\mathrm{C}_{104} \mathrm{H}_{124} \mathrm{O}_{2} \mathrm{Sn}_{4}, \quad M=1880.78, \mathrm{R}=0.0290$ for 4032 independent reflections. CCDC 1036416 and 1036417 contain the supplementary crystallographic data for this paper. These data can be obtained free of charge from the Cambridge Crystallographic Data Centre via www.ccdc.cam.ack.uk/data_request/cif.

[25] R. P. A. Bettens, D. Dakternieks, A, Duthie, F. S. Kuan, and E. R. T. Tiekink, Cryst. Eng. Comm., 2009, 11, 1362-1372.

[26] B. Zobel, M. Schurmann, K. Jurkschat, D. Dakternieks, and A. Duthie, Organometallics, 1998, 17, 4096-4104.

[27] R. S. Simons, L. Pu, M. M. Olmstead, and P. P. Power, Organometallics, 1997, 16, 1920-1925.

[28] E. Rivard, R. C. Fischer, R. Wolf, Y. Peng, W. A. Merrill, N. D. Schley, Z. Zhu, L. Pu, J. C. Fettinger, S. J. Teat, I. Nowik, R. H. Herber, N. Takagi, S. Nagase, and P. P. Power, J. Am. Chem. Soc., 2007, 129, 1619716208.

[29] Y. Peng, M. Brynda, B. D. Ellis, J. C. Fettinger, E. Rivard, and P. P. Power, Chem. Comm. 2008, 6042-6044.

[30] L. Pineda, V. Jancik, K. Starke, R. B. Oswald, and H. W. Roesky. Angew. Chem. Int. Ed. 2005, 45, 2602-2605.

[31] V. K. Belsky, N. N. Zemlyansky, N. D. Kolosova, and I. V. Borisova, J. Organomet. Chem., 1981, 215, 41-48.

[32] H. Puff, C. Bach, W. Schuh, and R. Zimmer, J. Organomet. Chem., 1986, 312, 313-322.

[33] M. F. Lappert, W.-P. Leung, C. L. Raston, A. J. Thorne, B. W. Skelton, and A. H. White, J. Organomet. Chem, 1982, 233, C28-C32.

[34] B. Wrackmeyer. Ann. Rep. NMR Spectrosc. G. A. Webb, Ed. 1999, 39, 218.

[35] J. P. Perdew, K. Burke, and M. Ernzerhof, Phys. Rev. Lett., 1996, 77, 3865-3868.

[36] J. P. Perdew, K. Burke, and M. Ernzerhof, Phys. Rev. Lett., 1997, 78, 1396.

[37] J. P. Perdew, M. Emzerhof, and K. Burke, J. Chem. Phys., 1996, 105, 9982-9985.

[38] C. Adamo and V. Barone, J. Chem. Phys. 1999, 110, 6158-6170.

[39] A. Schaefer, C. Huber, and R. Ahlrichs, J. Chem. Phys., 1994, 100, 5829-5835. 